\title{
SIFAT FISIK DAN MEKANIK PAPAN GIPSUM DARI LIMBAH KAYU AKASIA (Acacia mangium Willd) BERDASARKAN KADAR GIPSUM DAN UKURAN SERBUK KAYU
}

(Physical and Mechanical properties of Gypsum Board from Acacia (Acacia mangium Willd)

Wood Waste Based on Gypsum Content and Wood Powder Size)

\section{Ridho Pratama, M. Dirhamsyah, Nurhaida}

Fakultas Kehutanan Universitas Tanjungpura Pontianak. Jl. Daya Nasional Pontianak 78124 e-mail: ridhopratama269@gmail.com

\begin{abstract}
This study aims to examine the physical and mechanical properties of gypsum board from Acacia mangium Willd wood waste based on gypsum content and wood powder size. This study refers to the JIS A 5417-1992 standard. This research were conducted at Wood Work Shop laboratory for the preparation of raw materials, Wood Technology laboratory Faculty of Forestry for board making and testing the physical properties of gypsum boards, and PT. Duta Pertiwi Nusantara laboratory to test the mechanical properties of the gypsum board. The material used is A. mangium W. Wood powder, gypsum flour, water and borax. The study uses Factorial Completely Randomized Design (CRD) with two factors, namely factor A (gypsum content) which consists of gypsum content of 400\%, 500\% and $600 \%$ of the weight of $A$. mangium $W$. wood powder, and factors $B$ (wood powder size) consists of 20 mesh passes 40 mesh retained and 40 mesh passes 60 mesh retained. The results showed that the density $(600 \%$ gypsum content of 40 and 60 mesh retained wood powder size), moisture content, thickness swelling, MOE (600\% gypsum content of 40 and 60 mesh retained wood powder size) fulfill JIS A5417-1992 standard. The best gypsum board is gypsum board with gypsum content of 600\% with a wood powder size is 40 mesh.
\end{abstract}

Keyword: Acacia mangium, gypsum board, gypsum content, wood powder size.

\section{PENDAHULUAN}

Kebutuhan kayu sebagai bahan baku bangunan semakin meningkat. Kayu biasanya dibentuk menjadi papan untuk dijadikan dinding, pintu maupun jendela. Namun semakin lama kayu semakin sulit ditemukan karena kurang bijaknya dalam pengelolaan kayu dan membuat harga kayu semakin mahal. Untuk mengatasi hal tersebut salah satunya adalah dengan membuat papan tiruan dari limbah serbuk kayu.

Limbah serbuk kayu dapat diperoleh dari pabrik pengergajian kayu (sawmill).
Salah satu tempat yang mempunyai banyak limbah serbuk kayu yaitu sawmill CV Sari Fasifik. Menurut pihak Sawmill CV Sari Fasifik (2018), limbah berupa serbuk kayu sebesar $174.400 \mathrm{~cm}^{3}$ perharinya. Limbah serbuk kayu tersebut salah satunya berasal dari kayu Acacia mangium Willd atau biasa dikenal sebagai akasia daun lebar. Akasia daun lebar merupakan tumbuhan fast growing (cepat tumbuh) yang artinya dapat menghasilkan jumlah kayu yang banyak dalam waktu relatif cepat sehingga, penggunaan kayu ini akan membuat kontinuitas produk 
terjamin. Namun banyaknya limbah serbuk kayu tersebut tidak dimanfaatkan sama sekali sehingga mendorong peneliti untuk menggunakan limbah serbuk kayu tersebut sebagai bahan campuran papan gipsum. Hal ini didukung penelitian Hamdi (2014) yang menyatakan bahwa limbah penggergajian (serbuk kayu) dapat digunakan sebagai bahan campuran papan gipsum.

Papan gipsum adalah papan yang terbuat dari serbuk gipsum dengan serat/fiber dan campuran lainnya yang digunakan untuk plafon, dinding dan bahan konstruksi lainnya. Trisna et al. (2012), papan gipsum adalah produk jadi yang terbuat dari proses lanjutan material gipsum. Papan gipsum memiliki harga yang murah, ringan dan termasuk yang mudah dalam pemasangannya. Menurut College et al. (2014) papan gipsum adalah papan yang paling banyak digunakan di dunia dan termasuk bahan yang mudah untuk dikerjakan dan murah serta belimpah. Selain itu papan gipsum dapat menahan panas dan menghambat api dikarenakan serat/fiber serta kertas yang melapisi papan yang dapat menghambat rambatan api. Meskipun demikian, papan gipsum tidak terlalu kuat, mudah retak dan mudah menyerap air (Maail et al. 2006). Sifat papan gipsum yang kurang baik itu dapat diatasi dengan menambahkan bahan pengisi dalam pembuatannya. Menurut Noor (2007) penambahan serbuk kayu (maksimal 25\% dari berat gipsum) dapat meningkatkan kualitas papan gipsum.

Faktor yang mempengaruhi sifat fisik dan mekanik papan gipsum dengan serbuk gergajian adalah kadar gipsum dan ukuran serbuk kayu. Penelitian yang dilakukan Purwanto (2013) menggunakan 3 jenis kayu yaitu kayu Lua, Tarap dan Kembang dengan kadar gipsum 300\%, 400\% dan $500 \%$ mendapatkan hasil yaitu kadar gipsum tertinggi $(500 \%)$ dari serbuk kayu kembang dan ukuran serbuk kayu terbesar yaitu 40 mesh menghasilkan sifat mekanik yang paling baik. Penelitian yang dilakukan Hamdi (2013) menggunakan 3 jenis kayu yaitu kayu Lua, Tarap dan Kembang dengan kadar gipsum 300\%, 400\% dan 500\% mendapatkan hasil yaitu kadar gipsum tertinggi yaitu $500 \%$ dari serbuk kayu dan ukuran serbuk kayu terbesar yaitu 40 mesh menghasilkan papan gipsum dengan kerapatan, daya serap air dan pengembangan tebal yang memenuhi standar SNI 03-6434-2000. Berdasarkan hal diatas, maka penelitian ini akan menguji sifat fisik dan mekanik papan gipsum dari serbuk $A$. mangium Willd berdasarkan kadar gipsum dan ukuran serbuk kayu. Penelitian ini bertujuan untuk menguji sifat fisik dan mekanik papan gipsum dari limbah serbuk A. mangium Willd berdasarkan ukuran serbuk dan kadar gipsum. Manfaat dari penelitian ini adalah untuk meningkatkan variasi penggunaan limbah serbuk akasia dikarenakan kurangnya pemanfaatan limbah serbuk sehingga mengoptimalkan pemanfaatannya.

\section{METODE PENELITIAN}

Penelitian dilakukan di Laboratorium Wood Workshop Fakultas Kehutanan Universitas Tanjungpura Pontianak untuk persiapan bahan baku. Laboratorium Teknologi Kayu Fakultas Kehutanan Universitas Tanjungpura Pontianak untuk 
pembuatan papan serta Laboratorium PT Duta Pertiwi Nusantara Pontianak untuk melakukan pengujian Papan. Penelitian dilaksanakan mulai dari persiapan bahan, proses pembuatan papan dan pengujian papan selama \pm 2 bulan. Bahan yang digunakan adalah serbuk gergajian $A$. mangium yang diperoleh dari CV sawmill Sari Pasifik, tepung gipsum, oli, air, dan boraks. Alat yang digunakan adalah terpal, oven, timbangan analitik, baskom, cetakan ukuran $30 \mathrm{~cm} \times 30 \mathrm{~cm} \times 2,5 \mathrm{~cm}$, kaliper, Universal Testing Machine, tabung reaksi, termometer, termos, sterofoam, gerinda, alat tulis, kamera, penggaris, meshscreen, kempa manual dan plastik.

\section{Pengujian Suhu Hidrasi}

Pengukuran suhu hidrasi mengacu pada Sanderman dalam Kamil (1970). Gipsum sebanyak 150 gram dicampurkan dengan serbuk kayu akasia daun lebar 30 gram dan 3 gram boraks. Kemudian campuran gipsum, serbuk akasia daun lebar dan boraks ditambahkan air sebanyak $100 \mathrm{ml}$ dan diaduk hingga homogen. Setelah itu campuran tersebut dimasukkan ke dalam termos. Kemudian oli dituangkan ke dalam tabung reaksi seperempat dari tinggi tabung reaksi dan diletakan termometer ke dalam tabung reaksi. Setelah itu tabung reaksi dimasukkan ke dalam termos hingga menyentuh campuran sebelumnya. Termos ditutup dengan sterofoam yang diberi lubang untuk termometer. Perubahan suhu setiap satu jam sekali akan dicatat dan dilakukan terus menerus selama 24 jam. Berdasarkan penelitian LPHH Bogor dalam Putra (2017) untuk suhu hidrasi ada 3 kategori yaitu suhu diatas $41^{\circ} \mathrm{C}$ baik, suhu $36^{\circ} \mathrm{C}-41^{\circ} \mathrm{C}$ cukup baik, suhu dibawah $36^{\circ} \mathrm{C}$ tidak baik.

\section{Persiapan Bahan}

Serbuk kayu yang digunakan direndam dengan air dingin selama 48 jam. Serbuk kayu yang telah direndam dibuang airnya (ditiriskan). Setelah ditiriskan, serbuk kayu dijemur di bawah sinar matahari. Serbuk kayu kemudian diayak untuk mendapat ukuran serbuk kayu lolos 20 mesh tertahan 40 mesh dan lolos 40 mesh tertahan 60 mesh. Boraks digunakan sebanyak $1 \%$ dari kebutuhan tepung gipsum.

\section{Pembuatan Papan Gipsum}

Pembuatan papan gipsum dibuat dengan cara mencampurkan seluruh bahan hingga homogen. Selanjutnya adonan dimasukkan ke dalam cetakan kemudian ditutup. Selanjutnya cetakan dikempa dingin dengan kempa manual selama \pm 15 menit. Setelah itu papan diklem selama 24 jam. Papan yang telah diklem kemudian dikeluarkan dari cetakkan. Papan yang dihasilkan dikondisikan selama 2 minggu. Papan gipsum dipotong berdasarkan JIS A 5417-1992. Untuk mengetahui kualitas papan gipsum maka dilakukan pengujian sifat fisik dan sifat mekanik seperti: kerapatan, kadar air, pengembangan tebal, daya serap air, MOE dan MOR. Pengujian dilakukan berdasarkan standar JIS A54171992. Penelitian ini menggunakan percobaan Faktorial Rancangan Acak Lengkap (RAL) dengan 3 kali ulangan. Faktor yang digunakan adalah kadar gipsum dan ukuran serbuk kayu.

HASIL DAN PEMBAHASAN

Pengujian Pendahuluan

Suhu hidrasi 
Suhu hidrasi dilakukan untuk melihat kesesuaian serbuk kayu akasia daun lebar sebagai bahan baku papan gipsum. Hasil hidrasi dapat dilihat pada Gambar 1.

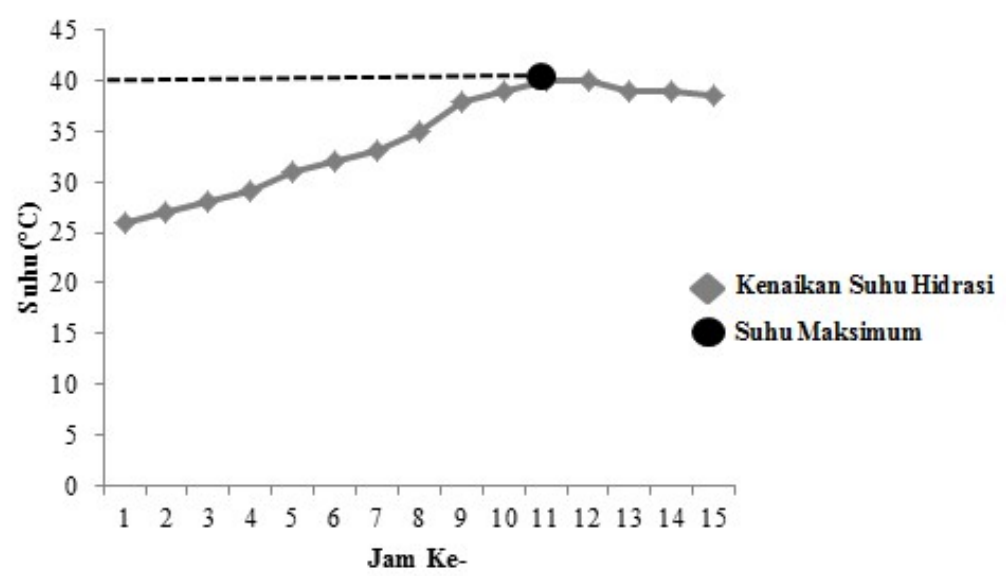

Gambar 1. Pengukuran Suhu Hidrasi (Measurement of Hydration Temperature)

Suhu tertinggi terjadi pada jam ke-11 yang mencapai suhu $40^{\circ} \mathrm{C}$. Adanya kenaikan suhu pada pengujian hidrasi diakibatkan oleh adanya reaksi eksotermik antara gipsum, serbuk kayu dan air. Nilai tersebut menunjukkan bahwa serbuk kayu akasia daun lebar yang digunakan memberikan pengaruh baik sebagai bahan pengisi papan gipsum. Hal ini mengacu pada klasifikasi LPHH Bogor dalam Putra (2017) bahwa untuk hasil uji hidrasi yang berada antara $36^{\circ} \mathrm{C}$ hingga $41^{\circ} \mathrm{C}$ termasuk dalam kategori cukup baik sehingga serbuk kayu akasia daun lebar dapat digunakan sebagai bahan papan gipsum. Kesesuaian suhu dalam kategori sedang menunjukkan bahwa serbuk kayu akasia daun lebar tidak mengandung banyak zat ekstraktif yang dapat menghambat pengerasan gipsum, sehingga ikatan antara gipsum dan serbuk kayu dapat berlangsung dengan baik.

\section{Sifat Fisik Papan Gipsum}

\section{Kerapatan}

Nilai rerata kerapatan papan gipsum hasil penelitian ini disajikan pada Gambar 2.

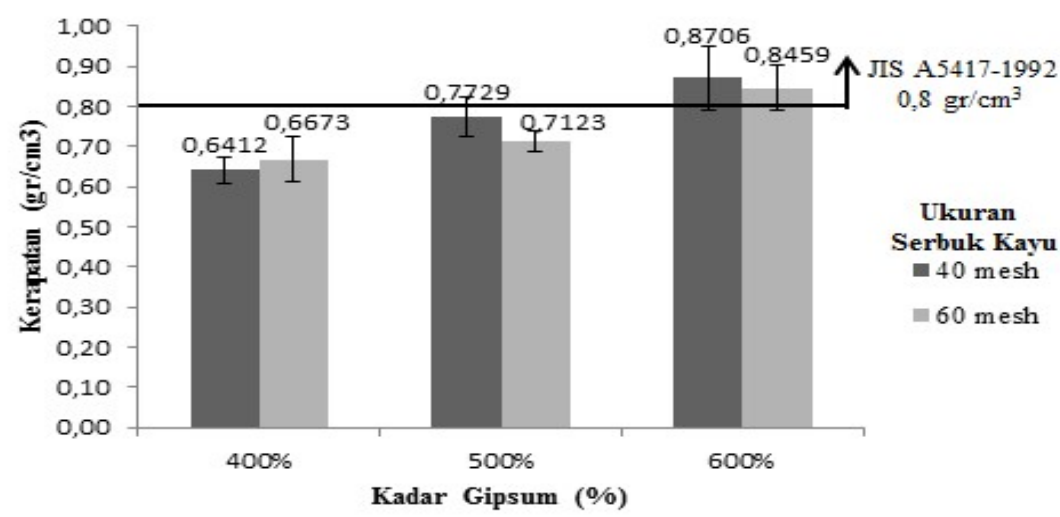

Gambar 2. Nilai Rerata \pm SD Kerapatan Papan Gipsum (The average $\pm S D$ density of Gypsum Board) 
Seluruh nilai kerapatan papan gipsum tidak ada yang memenuhi kerapatan target $\left(1,2 \mathrm{gr} / \mathrm{cm}^{3}\right)$. Hal ini dikarenakan papan yang dibuat melebihi target ketebalan yang diinginkan. Hal ini diduga saat pelepasan dari cetakan dan klem, papan mengembang kembali, sehingga susunan komponen bahan dalam papan tidak rapat dan memungkinkan adanya pori-pori papan yang tidak tertutup sehingga menyebabkan tebal papan menjadi besar sementara kerapatan papan menjadi kecil. Hal ini sejalan dengan Bakri et al. (2006) yang melakukan pengekleman selama 24 jam dan menyatakan bahwa kerapatan tidak tercapai dikarenakan ketebalan papan melebihi target.

Hasil sidik ragam menunjukan bahwa kadar gipsum memberikan pengaruh sangat nyata terhadap kerapatan papan gipsum. Kerapatan papan gipsum bertambah seiring dengan meningkatnya kadar gipsum yang ditambahkan. Hal ini diduga karena gipsum dengan kadar yang tinggi akan mengikat partikel kayu lebih erat sehingga kerapatan papan gipsum semakin tinggi. Hasil penelitian ini didukung penelitian Hamdi (2013), yang menyatakan bahwa semakin banyak gipsum yang digunakan, maka semakin erat ikatan antar serbuk kayu yang menyebabkan kerapatan semakin tinggi. Shiroma et al. (2016) menyatakan nilai kerapatan papan rendah dikarenakan penggunaan serbuk kayu yang banyak (penggunaan gipsum sedikit) yang menyebabkan porositas kayu semakin tinggi. Hasil keseluruhan penelitian menunjukkan hanya satu perlakuan yang memenuhi standar JIS A 5417:1992 yaitu pada papan gipsum dengan kadar gipsum $600 \%$ dari berat serbuk kayu. Sedangkan papan gipsum dengan kadar gipsum 400\% dan $500 \%$ dari berat serbuk kayu tidak memenuhi standar JIS A5417-1992.

\section{Kadar Air}

Nilai rerata kadar air papan gipsum disajikan pada Gambar 3.

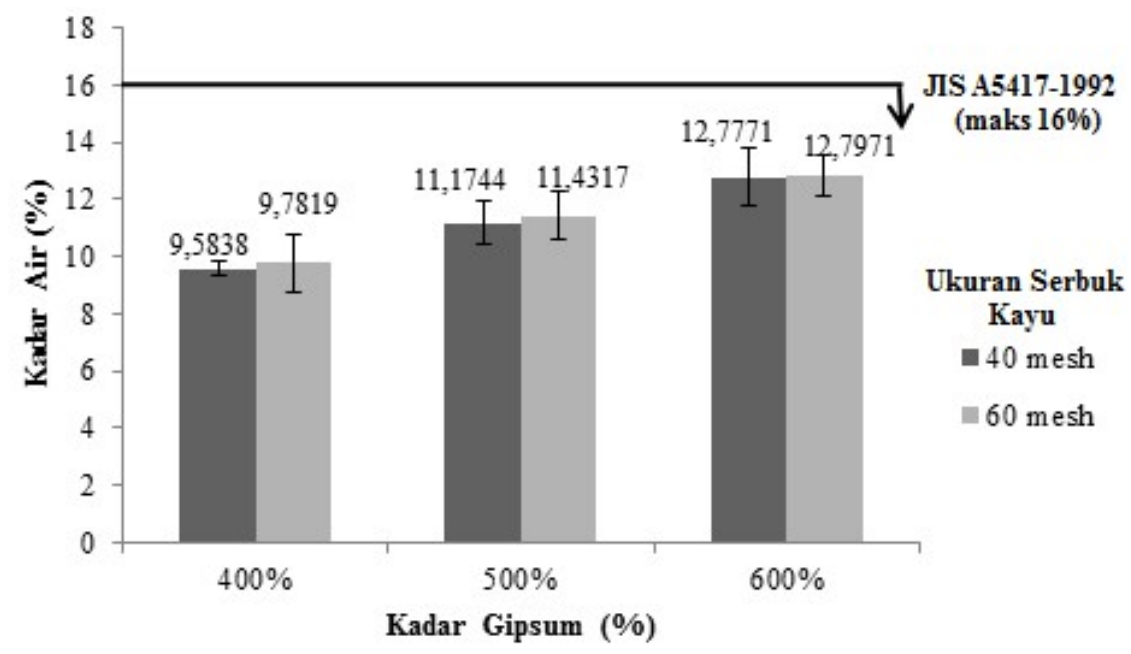

Gambar 3. Nilai Rerata \pm SD Kadar Air Papan Gipsum (The average $\pm S D$ moisture content of Gypsum Board)

Hasil sidik ragam menunjukan pengaruh sangat nyata terhadap bahwa kadar gipsum memberikan kerapatan papan gipsum. Semakin 
tinggi penambahan gipsum, semakin tinggi pula kadar air papan gipsum. Hal ini diduga karena penambahan gipsum yang tinggi menciptakan struktur papan yang rapat dan pori-pori papan yang kecil, sehingga air yang tertahan pada papan gipsum akan sulit menguap yang menyebabkan kadar air semakin tinggi. Selain itu, gipsum memiliki kemampuan dalam menyerap air, sehingga semakin banyak gipsum yang digunakan maka air yang diikat akan semakin banyak sehingga meningkatkan kadar air. Hasil penelitian ini didukung penelitian Hendrik dalam Amaliah dan Hamdi (2015), semakin banyak penambahan gipsum pada papan, maka kadar air papan akan semakin tinggi dikarenakan gipsum memiliki sifat absorben air sehingga air yang diikat semakin banyak. Seluruh nilai kadar air papan gipsum yang dihasilkan memenuhi standar JIS A 5417-1992 yang mensyaratkan kadar air maksimal $16 \%$.

\section{Daya Serap Air}

Nilai rerata daya serap air papan gipsum disajikan pada gambar 4 .

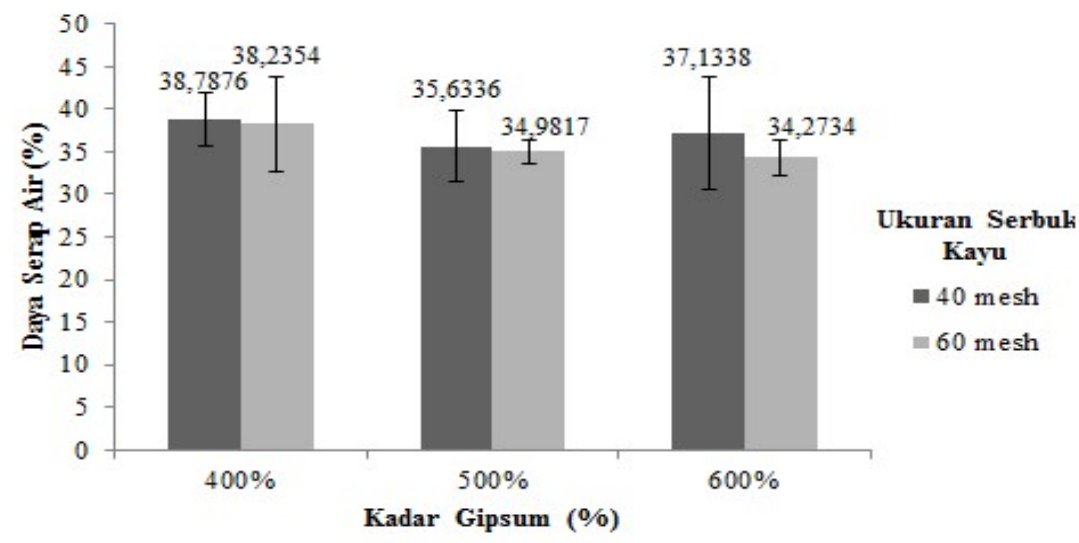

Gambar 4. Nilai Rerata \pm SD Daya Serap Air Papan Gipsum (The average \pm SD water absorption of Gypsum

\section{Board)}

Hasil penelitian menunjukkan bahwa semakin sedikit kadar gipsum semakin tinggi pula daya serap air papan gipsum. Menurut Trisnayanti et al. (2014) menyatakan bahwa daya serap air semakin tinggi apabila serbuk kayu semakin bertambah. Hal ini diduga papan gipsum dengan serbuk kayu yang lebih banyak akan menyebabkan kerapatan papan menjadi rendah sehingga air lebih mudah masuk ke dalam pori-pori papan gipsum. Papan gipsum yang memiliki kerapatan rendah memiliki pori-pori yang lebih banyak dibanding dengan papan gipsum berkerapatan tinggi, sehingga saat papan gipsum direndam kedalam air papan gipsum tersebut akan lebih mudah menyerap air yang menyebabkan air yang diserap menjadi lebih banyak dibanding papan gipsum berkerapatan tinggi.

Nilai rerata daya serap air menunjukkan semakin besar ukuran partikel maka semakin banyak penyerapan air. Menurut Hamdi (2013) menyatakan bahwa ukuran serbuk kayu yang besar memiliki rongga yang lebih 
banyak pada papan sehingga lebih mudah menyerap air. Nilai daya serap air tidak disyaratkan dalam JIS A 54171992. Pengujian dilakukan karena berpengaruh terhadap ketahanan papan dalam penggunaannya yang berhubungan langsung dengan cuaca.

Pengembangan Tebal

Nilai rerata pengembangan tebal papan gipsum disajikan pada Gambar 5.

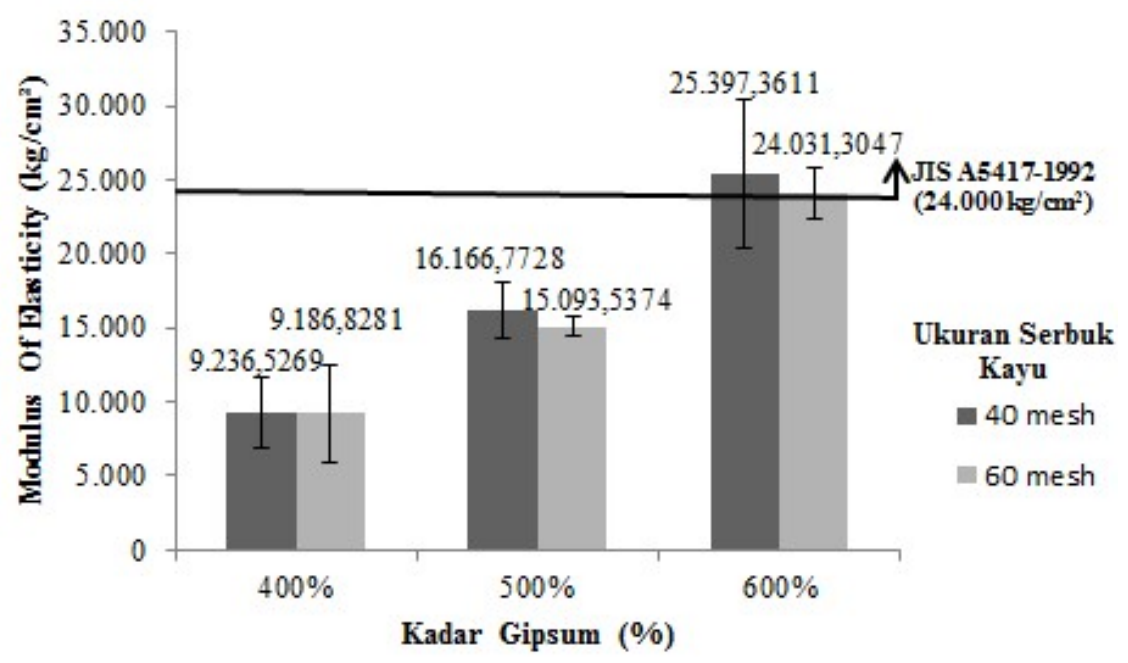

Gambar 5. Nilai Rerata \pm SD Pengembangan Tebal Papan Gipsum (The average \pm SD thickness swelling of Gypsum Board)

Nilai rerata pengembangan tebal menunjukkan bahwa semakin rendah kadar gipsum semakin rendah pula pengembangan tebal papan. Hamdi (2013) menyatakan bahwa papan gipsum dengan kadar gipsum yang tinggi yang berarti jumlah serbuk kayu lebih sedikit akan mengikat serbuk kayu lebih erat sehingga kerapatan papan gipsum semakin tinggi yang menyebabkan air sulit masuk sehingga pengembangan tebal berkurang. Nilai rerata pengembangan tebal menunjukkan semakin besar ukuran serbuk kayu maka semakin besar pengembangan tebalnya. Menurut Armaya et al. (2013) semakin besar ukuran serbuk kayu maka pengembangan tebalnya akan semakin besar dikarenakan serbuk kayu besar akan membuat banyak rongga pada papan sehingga air lebih mudah masuk ke dalam papan yang menyebabkan pengembangan tebal meningkat. Pengembangan tebal berhubungan dengan daya serap air. Umumnya semakin tinggi daya serap air, maka semakin tinggi pula pengembangan tebalnya. Seluruh nilai pengembangan tebal papan gipsum pada penelitian ini memenuhi standar JIS A 5417-1992 yang mensyaratkan nilai pengembangan tebal maksimal 8,3\%

Sifat Mekanik Papan Gipsum

MOE (Modulus Of Elasticity)

Nilai rerata MOE papan partikel dapat dilihat pada Gambar 6. 


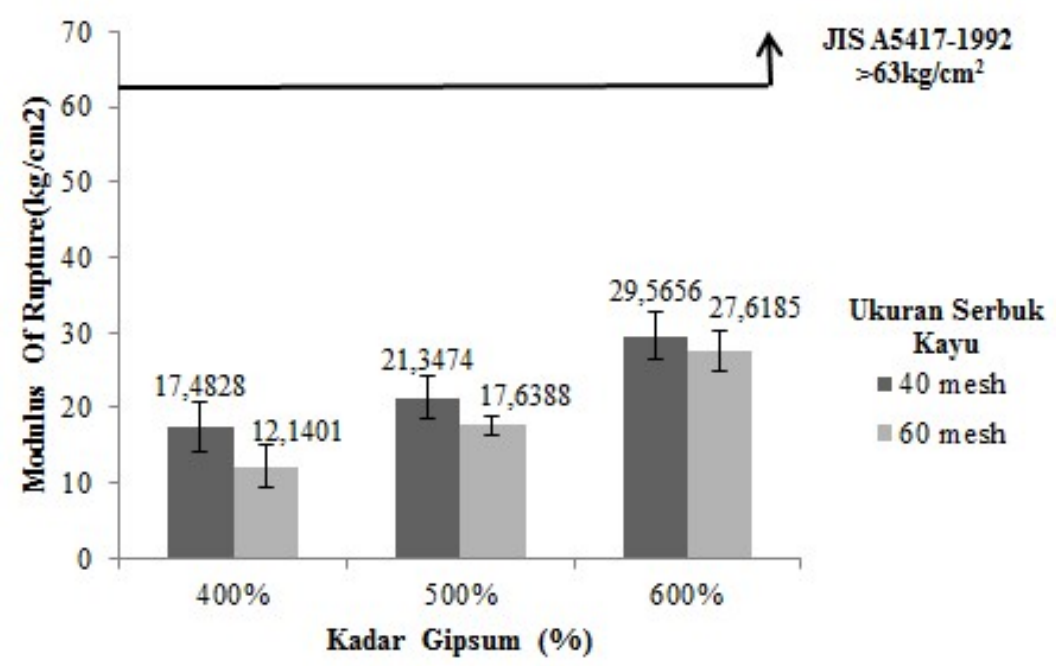

Gambar 6. Nilai Rerata \pm SD MOE Papan Gipsum (The average \pm SD MOE of Gypsum Board)

Hasil sidik ragam menunjukan bahwa kadar gipsum berpengaruh terhadap nilai Modulus Of Elasticity papan gipsum. Semakin banyak kadar papan gipsum maka semakin besar pula nilai MOE papan. Hal ini diduga karena serbuk gipsum yang lebih banyak akan lebih kuat mengikat serbuk kayu sehingga elastisitas papan gipsum meningkat. Papan gipsum dengan nilai MOE yang lebih tinggi cenderung memiliki kerapan yang tinggi pula. Semakin besar kerapatan maka susunan serbuk kayu menjadi lebih padat sehingga ketika papan diberi beban, papan akan menahan beban lebih lama sehingga memberikan hasil MOE yang tinggi. Hasil penelitian ini didukung penelitian Sudin dan Shaari (1991), semakin banyak kadar gipsum semakin tinggi pula kekuatan lenturnya. Simbolon et al. (2015) yang menyatakan bahwa jumlah perekat yang lebih banyak akan memperkuat ikatan antar serbuk kayu sehingga nilai MOE semakin tinggi pula.

Nilai MOE yang memenuhi standar JIS A5417-1992 adalah papan gipsum dengan kadar gipsum 600\% ukuran serbuk kayu lolos 20 mesh tertahan 40 mesh dan papan gipsum dengan kadar gipsum $600 \%$ ukuran serbuk kayu lolos 40 mesh tertahan 60 mesh. Nilai MOE standar JIS A5417-1992 mensyaratkan minimal $24.000 \mathrm{~kg} / \mathrm{cm}^{2}$.

MOR (Modulus Of Rupture)

Nilai rerata MOR papan partikel dapat dilihat pada Gambar 7. 


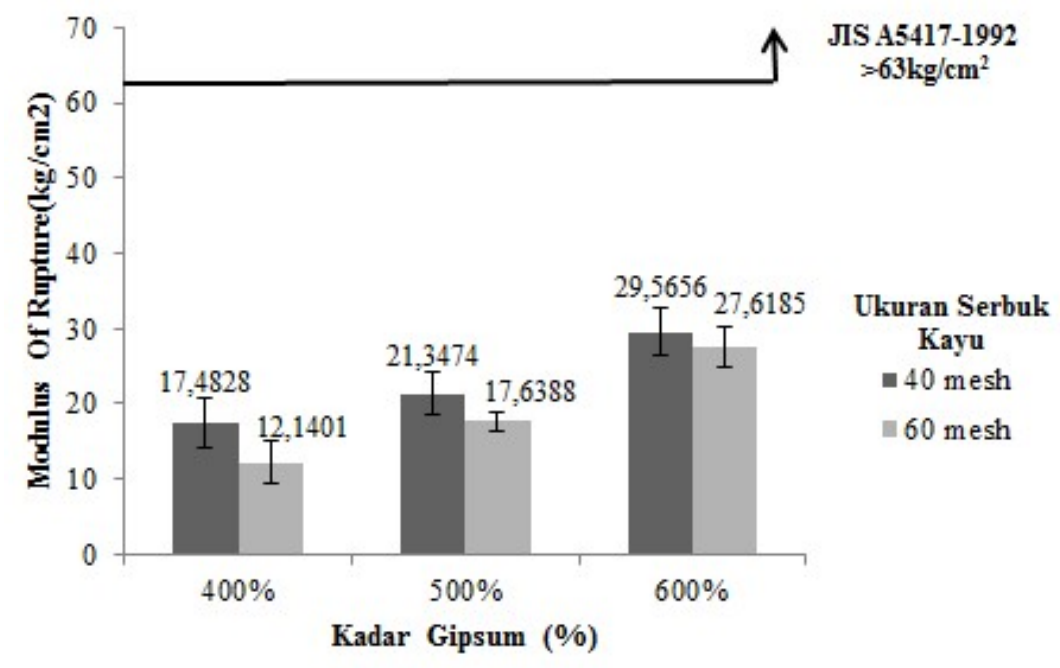

Gambar 7. Nilai Rerata \pm SD MOR Papan Gipsum (The average \pm SD MOR of Gypsum Board)

Hasil sidik ragam menunjukkan bahwa faktor kadar gipsum berpengaruh sangat nyata terhadap nilai MOR papan gipsum. Semakin banyak penambahan gipsum semakin tinggi nilai MOR nya. Menurut Hamdi (2014), semakin tinggi kadar gipsum semakin tinggi pula modulus patah (MOR). Peningkatan nilai MOR ini diduga karena dengan meningkatnya jumlah gipsum (perekat) yang digunakan maka ikatan antar serbuk kayu akan semakin tinggi sehingga meningkatkan kemampuan papan untuk menahan beban hingga batas maksimum. Sejalan dengan Noor (2007) semakin sedikit serbuk kayu yang digunakan, ikatan antar serbuk kayu akan lebih kuat sehingga nilai MOR semakin tinggi.

Hasil sidik ragam menunujukan bahwa ukuran serbuk kayu berpengaruh nyata terhadap nilai MOR yang dihasilkan. Semakin besar ukuran serbuk kayu maka semakin besar pula nilai MOR nya. Hal ini diduga karena semakin besar ukuran serbuk kayu maka semakin kecil luas permukaannya sehingga membutuhkan gipsum yang lebih sedikit untuk mengikat serbuk kayu. Hasil penelitian ini didukung penelitian Purwanto (2013) yang menyatakan papan gipsum dengan ukuran serbuk kayu yang lebih besar akan memiliki nilai MOR yang lebih besar dibanding papan gipsum dengan ukuran serbuk kayu kecil. Hal serupa juga dari Adamopoulos et al. (2015) menyatakan papan gipsum dengan serbuk kayu kasar memiliki kekuatan yang lebih tinggi dibanding dengan papan gipsum serbuk kayu halus. Seluruh nilai MOR papan gipsum pada penelitian ini tidak memenuhi standar JIS A5417-1992 yang mensyaratkan nilai MOR minimal $63 \mathrm{~kg} / \mathrm{cm}^{2}$.

\section{KESIMPULAN}

1. Faktor kadar gipsum berpengaruh sangat nyata terhadap kerapatan, 
kadar air, Modulus of Elasticity (MOE) dan Modulus Of Rupture $(M O R)$. Faktor ukuran serbuk kayu berpengaruh nyata terhadap Modulus Of Rupture (MOR). Untuk interaksi terhadap faktor kadar gipsum dan ukuran serbuk kayu tidak berpengaruh nyata terhadap kerapatan, kadar air, pengembangan tebal, daya serap air, Modulus Of Elasticity (MOE) dan Modulus Of Rupture (MOR).

2. Seluruh nilai kadar air dan pengembangan tebal papan gipsum memenuhi standar JIS A5417-1992. Pada kerapatan dan MOE pada papan gipsum yang memenuhi standar hanya pada papan gipsum dengan kadar gipsum 600\% dengan ukuran serbuk kayu lolos 20 mesh tertahan 40 mesh maupun ukuran lolos 40 mesh tertahan 60 mesh. Nilai MOR pada papan gipsum tidak memenuhi standar JIS A5417-1992.

3. Berdasarkan total nilai rekapitulasi papan gipsum terbaik terdapat kadar gipsum 600\% dari massa serbuk kayu dan ukuran serbuk limbah kayu akasia daun lebar (A. mangium W.) lolos 20 mesh tertahan 40 mesh dan memenuhi standar JIS A 54171992 kecuali nilai Modulus of Rupture (MOR).

\section{SARAN}

1. Perlunya dilakukan penelitian lebih lanjut untuk mengatasi kerapatan yang tidak sesuai target dan untuk meningkatkan nilai MOE (Modulus Of Elasticity) dan MOR (Modulus Of Rupture).
2. Papan yang akan diuji sebaiknya diberi pelapis berupa kertas agar memperbaiki sifat fisik dan mekanik papan gipsum.

\section{DAFTAR PUSTAKA}

Adamopoulos S, Dafni F, Elias V, Costas P. 2015. Manufacturing and Properties of Gypsum-Based Products with Recovered Wood and Rubber Materials. BioResource 10(3): 5573-5585.

Armaya R, Evalina H, Tito S. 2013. Karakteristik Fisis dan Mekanis Papan Semen Bambu Hitam (Gigantochloa atroviolacea Widjaja) dengan Dua Ukuran Partikel. Peronema Forestry Science Journal 2 (1)

Bakri, Gunawan E, Sanusi D. 2006. Sifat Fisik dan Mekanik Komposit Kayu Semen-Serbuk Gergaji. Jurnal Parrenial 2(1): 38-41

College JW, Shane L, Mark H. 2014. System And Method For The Production Of Gypsum Board Using Starch Pellets. United State Patent Document $(8,882,943$ B2)

Hamdi S, Arhamsyah. 2010. Sifat Fisis Mekanis Papan Partikel dari Limbah Kayu Gergajian Berdasarkan Ukuran Partikel. Jurnal Riset Industri Hasil Hutan 2 (2): 13-17

Hamdi S. 2013. Sifat Fisis Papan Gypsum dari Limbah Gergajian Kayu. Jurnal Riset Industri Hasil Hutan 5 (1): 9-15

Hamdi S. 2014. Sifat Mekanik Papan Gypsum dari Serbuk Limbah Kayu Non Komersial. Jurnal Riset Industri Hasil Hutan 6 (2): 1-6 
Indera RK, Enden M, Naufal F. 2018. Stabilisasi Tanah Lempung Lunak dengan Manfaat Limbah Gypsum dan Pengaruhnya Terhadap Nilai California Bearing Ratio (CBR). Jurnal Fondasi 7 (1): 22-31

Maail RS, Dede H, Yusuf SH. 2006. Pembuatan Semen-Gypsum dari Core Kenaf (Hibiscus cannabinus L.) Menggunakan Teknologi Pengerasan Autoclave. Jurnal Parennial 2 (2): 12-18

Noor GS. 2007. Pengaruh Variasi Berat Partikel Terhadap Sifat Papan Gipsum. Badan Litbang Daerah Provinsi Kalimantan Selatan, Banjarmasin.

Purwanto D. 2013. Papan Gypsum dari Serbuk Kayu dan Senyawa Bor Terhadap Sifat Mekanik dan Uji Bakar. Jurnal Riset Industri Hasil Hutan 5 (2): 1-8

Putra IKAAA, M. Dirhamsyah, Gusti ET. 2017. Mechanical and Physical Properties Of Cement Particle Board Made From Trunk Of Pandan Mengkuang (Pandanus atrocarpu Griff). Jurnal Hutan Lestari 5 (4): 908-915
Shiroma L, Camarin G, Beraldo AL. 2016. Effect of Wood Particle Treatment on The Properties of Gypsum Plaster Pastes and Composites. Matêria (Rio de Janerio) 4

Simbolon IL, Tito S, Rudi H. 2015. Pengaruh Ukuran Partikel dan Komposisi Semen- Partikel terhadap Kualitas Papan Semen dari Cangkang Kemiri (Aleurites moluccana Wild). Peronema Forestry Science 4 (1)

Trisna H, Alimin M. 2012 Analisis Sifat Fisis dan Mekanik Papan Komposit Gipsum Serat Ijuk Dengan Penambahan Boraks (Dinatrium Tetraborat Decahydrate). Jurnal Fisika Unand 1 (1): ISSN 2302-849

Trisnayanti Y, Eko S, M Lutfi F, Irwan K. 2014. Mutu Papan Gipsum dari Serat Daun Nanas dan Serbuk Gergaji Kayu Meranti dan Implementasinya Pada Pembelajaran Fisika. Jurnal $\begin{array}{lll}\text { Pendipa } & 1 & \text { (1): } \quad 33-41\end{array}$ 